\title{
Study of Land Potential and Suitability for Development Estate Crops on Buru Island, Moluccas Province, Indonesia
}

\author{
Marthen P. Sirappa (Corresponding Author) \\ Researches of Assessment Institute for Agricultural Technology of West Sulawesi \\ Kompleks Perkantoran Pemerintah Provinsi Sulawesi Barat, Jln. H. Abdul Malik Pattana \\ Endeng, Mamuju, Sulawesi Barat, Indonesia \\ E-mail: mpsirappa@gmail.com; mpsirappa_64@yahoo.co.id
}

Edwen D. Waas

Researches of Assessment Institute for Agricultural Technology of Moluccas

J1. Chr. Soplanit Rumah Tiga Ambon, Indonesia

\begin{abstract}
Andriko Noto Susanto
Head of Indonesian Center for Food Crops Research and Development

J1. Merdeka No. 147. Bogor 16111 - Jawa Barat, Indonesia
\end{abstract}

Received: April 1, 2018

doi:10.5296/jas.v6i3.13455
Accepted: April 16, 2018

URL: https://doi.org/10.5296/jas.v6i3.13455

\begin{abstract}
Moluccas widely recognized by the world community as a centre of high genetic diversity, including commodities producer of high economic value, such as estate crops. Although Moluccas has substantial resources, but has not been able to provide adequat e welfare for society because natural resources are available not optimally managed. Therefore, it is necessary to study the potential of land for the development of the estste crops. This research aims to determine the land potential and his referrals use for the development of estate crops on Buru Island (Buru and Southern Buru Regency). The methodology used was a desk study of some libraries and field observation. Land potential of Buru Island for developing a estate crops based on data analysis and use of existing biophysical taking into account the status of
\end{abstract}


the forest is an area of 86,140 ha covering an area of moderate to high potential area of $58,650 \mathrm{ha}$, and low potential areas covering an area of 27,490 ha with limiting factor drainage, rooting conditions, nutrient retention, slope, rooting conditions, floods, water availability, and slope. Wherever according by Agro-Ecological Zone (AEZ) approach from AIAT Moluccas with using AEZ analysis data, present land use, and statistical data for 8 years (2009 - 2016) is an area of 34,923.36 ha with covering sub zone II ax 15,952.78 ha, sub zone II ax.i 8,924.26, sub zone II ay 5,887.99 ha, and sub zone II ay.i 4,158.33 ha.

Keywords: Land potential, suitability, estate crops, Buru Island, AEZ approach

\section{Introduction}

Agricultural development policy refers to the agricultural area layout should consider the feasibility, biophysical, economic, social and cultural, so that outcomes could improve the lives of farmers and the sustainability of agricultural systems. Therefore, the development of innovative approaches to agricultural research and agricultural development in accordance with the vision of Indonesia, which is building a farm with agro ecological zone (AEZ) approaches (Kasryno et al. 2002).

According Wiradisastra (1996), agricultural development by AEZ approach is sorting an agricultural development area into units smaller and have relatively homogeneous characteristics so that the recommendations given in accordance with the needs and potential of the region owned farms. Plantation sector has a very important role in the strategic and national development, especially in improving the prosperity and welfare of the people. The main target is the development of plantation planters improving standards of living as whole and sustainable farming systems by implementing integrated sustainable plantations.

Leading commodities development strategies should be implemented based on the principle of benefit and sustainability and integration. To achieve these objectives, the development should be based on potential plantation land, primarily directed at the land suitability class is suitable (S1) and is quite suitable (S2). To be able to utilize resources in a focused and efficient land necessary to provide comprehensive data and information on the climate, soil and other physical properties of the environment, as well as the growing requirements of the crop.

Data climate, soil, and other physical properties of the environment that influence plant growth and the management aspects need to be identified through the survey and mapping of land resources. Land resources data is required primarily for the benefit of agricultural development planning and development. The data generated from the survey and mapping of land resources is still difficult to be used by the user (users) for a plan without any interpretation for certain purposes (http:/bbsdlp.litbang.deptan.go.id/). Land evaluation is an approach or a way to assess the potential of land resources. Land evaluation results will provide information and /or direction of land use and value of production expectations are likely to be obtained.

Dent \& Young (1981) states that the land evaluation is the process of estimating the potential of land for alternative kinds of use, is one of the important components in the process of land 
use planning. According to FAO (1976), suitability of land or land suitability classification is a way of a land suitability for a particular use. While the land suitability classification is the appraisal process and grouping of units of land according to its suitability for a particular use (Hakim et al. 1986). One system used in this study is a framework for land suitability evaluation of land suistability the FAO. Land suitability assessment is divided into 4 levels of detail, ie order, class, subclass, and unit (Rossiter 1994; Djaenudin et al. 1993; Ritung et al. 2011), but was commonly used only to the subclass level.

Potential of an area for the development of agriculture is essentially determined by the match between the physical nature of the environment and land use requirements or the equirements of growing plants (Department of Agriculture 1997). Each agricultural commodity production to be able to grow and require specific growing conditions. According Djaenudin et al. (2003), commodities are cultivated on the land in accordance with the requirements of the growth will be able to produce optimally with high quality and requires relatively low inputs. Therefore, the potential and suitability of land as well as inhibiting factors for the development of a commodity to know in order to set the most appropriate commodity (Rossister \& van Wambeke 1997).

Buru Island is one of a relatively large island in the Moluccas region with an area of approximately 860.787 ha (Moluccas Provincial Agriculture Office 2008). Potential land resource area is quite diverse because of differences in climate, parent material, soil, and topography/relief. The diversity of the land resource potential indicates the need for a proper land use planning, optimal and sustainable. Data and information of land resources is necessary to support agricultural development planning. This paper aims to provide information on the potential use of land and direction for the development of the estate crops on the Buru Island.

\section{Materials and Methods}

\section{Reshaping Analysis Map of Agro-Ecology Zone (AEZ)}

AEZ realignment map aims to validate the map of AEZ long Buru, which includes the districts of South Buru. AEZ map is a map spatial agricultural development for macro planning, including estate planning. In this mapping factor slope, soil, climate, and land use now (present land use) serve as the basis for zoning. Stages of the preparation of the map AEZ described below.

Preparation of maps/data. Land resource data, includes map RePPProT 1:250,000 scale soil map $1: 100,000$ or $1: 250,000$ scale, temperature and rainfall data from multiple weather stations and climate graduated there in the area over the last 10 years, the data/information relating the socioeconomic situation, maps Joint Operational Geographic (JOG) and administrative maps prepared.

Interpretation of the data. To specify an alternative commodity to be commercialized performed using Expert System software. Climate data and other resources that have been collected are prepared in accordance with the predetermined format to get agroecological zoning alternatives with commodities that have the potential to be developed in the zone. 
Proper overlap (overlay). Overlap exactly done to map AEZ with forest status maps and present land use. It aims to determine whether the region has seen in the manner intended, not suitable for use is lower than its capacity or is not appropriate because it is used beyond its capacity. At this stage also determined whether an area is needed intensification, extension or rehabilitation or conservation in the form of reforestation.

Completion map. Completion of the map is intended to explain the symbols in the map unit AEZ by making the legend map. The map legend provides the information contained in each set of maps covering AEZ: symbol zones, temperature regime (elevation), moisture regime, physiography, slope, soil group (Soil Survey Staff 1998), drainage and agricultural development zoning/forestry consisting of alternative production systems and commodities.

\section{Criteria Used as Basis of AEZ Map}

The criteria used in the preparation of AEZ map is:

1. Moisture regime, distinguished by 'humid (x)' if the dry months is equal to or less than 3 months, 'a little dry (y)' if the dry months between 4 to 7 months. If the state of the land is always inundated either permanently or periodically then given the symbol ' $z$ '.

2. Temperature regime, divided into 3 groups: hot temperature regime/ isohipertermik (a) if the difference in average air temperature of the warmest and coldest daily greater than $5^{\circ} \mathrm{C}$ (the area with an altitude of $<750 \mathrm{~m}$ above sea level/asl), the temperature cool/isothermic (b) if the difference average air temperature of the warmest and coldest day of less than $5^{\circ} \mathrm{C}$ (altitude $>750$ to 2,000 $\mathrm{m}$ asl.), and cold temperatures (c) at altitude $>2,000 \mathrm{~m}$ asl.

3. Relief, there are eight (8) groups based on the state of the ground zone, topography and land use types, namely:

a. Zone I is the area with slope $>40 \%$, the type of land use for forestry;

b. Zone II is the area with slopes 15 - 40\%, the type of land use for plantation (annual crops);

c. Zone III is the area with slopes between $8-<15 \%$ with the type of land for agro-forestry agro- forestry);

d. Zone IV is the area with slopes between $0-<8 \%$ with the type of land use for food crops;

e. Zone $\mathrm{V}$ is the region with the slope $<3 \%$, peat soil type to the type of land use for horticulture (shallow peat with thickness $<150 \mathrm{~cm}$ ) or forestry (deep peat with thickness $>$ $150 \mathrm{~cm})$

f. Zone VI is the region with the slope $<3 \%$ in the acid sulfate soil or saline soil by land use type for fisheries (aquaculture) or to forest (mangrove);

g. Zone VII is a region with a slope $<3 \%$ with a growing set of soil from quartz with the type of land use for forestry beach/marsh (pandanus);

h. Zone VIII is the area with slopes $<8 \%$ in shallow or rocky soil with the type of land use for livestock (pasture). 


\section{Macrothink}

Symbol 'i' on agroecological subzona means the use of land in accordance with its designation now means the area should diintensifikasi.

\section{Field Verification}

Verification is done to get a general overview of efforts by farmers and plantation as well as match results, with the actual conditions in the field.

\section{Data Collection}

Data collected included primary and secondary data. Collection of secondary data obtained from the CBS, districts, and related agencies, including acreage, harvested area, production and productivity of plantation crops. Primary data were collected with participatory rural approach

\section{Result And Discussion}

\section{Climate of Buru Island}

Climate of northern regions of Buru Island (Namlea) including Awa categorized according to Koppen classification and category class D according to Schmidt and Ferguson with an average of 6.1 months and 4.2 months of dry wet, while areas of Buru Island and southern central part, including Afa according to the Koppen classification and class B category according to Schmidt and Ferguson with an average of 8.4 months and 2.6 months wet dry (Table 1). Oldeman based classification, regional climate Namlea included in class E, which is an area with a wet month less than 3 months in a row and the long dry months, while the area Leksula including climate type $\mathrm{C} 1$, ie wet month over 5 months and in a small area of adjacent to the mountains to have a different climate class.

Table 1. Rainfall Average Monthly of Buru Island

\begin{tabular}{|c|c|c|c|c|c|c|c|c|c|c|c|c|}
\hline \multirow{2}{*}{ Station } & \multirow{2}{*}{$\begin{array}{c}\text { In } \\
\text { Obser-vation }\end{array}$} & \multicolumn{3}{|c|}{$\begin{array}{c}\text { Number of } \mathrm{DM}<60 \\
\mathrm{~mm}\end{array}$} & \multicolumn{3}{|c|}{$\begin{array}{c}\text { Number of WM > } \\
100 \mathrm{~mm}\end{array}$} & \multirow{2}{*}{ Q } & \multirow{2}{*}{$\begin{array}{l}\text { Schmidt \& } \\
\text { Fergusonn }\end{array}$} & \multirow{2}{*}{\multicolumn{2}{|c|}{ KoppeıOldeman }} & \multirow[t]{2}{*}{$\begin{array}{c}\text { Annual } \\
\text { Rainfall (mm) }\end{array}$} \\
\hline & & Mean & Max & Freq & Mean & Max & Freq & & & & & \\
\hline Namlea & 20 & 4.2 & 7 & 1 & 6.1 & 10 & 1 & 68.8 & $\mathrm{D}$ & Awa & $\mathrm{E}$ & 1,388 \\
\hline Leksula & 20 & 2.6 & 8 & 2 & 8.4 & 11 & 3 & 30.9 & B & Afa & $\mathrm{C} 1$ & 2,919 \\
\hline
\end{tabular}

Sources: Moluccas Provincial Agriculture Office (2008)

Water and climate is one factor limiting plant growth. Water management and climate plays a very important and is one key to the success of the increased production of crops on dry land. Water management technology depends on the climatic conditions of a region. Climate technologies and water management is important in dryland include rain harvesting technologies (water harvesting), climate prediction technology, as well as the determination of planting and cropping patterns. 


\section{1) Macrothink}

\section{Soil Type of Buru Island}

Soil types found at Buru Island include Histosols (Terric Sulfisaprists and Typic Sulfihemits), Entisols (Sulfic Fluvaquents, Typic Fluvaquents, Aquic Udifluvents, Lithic Udorthents, Typic Udorthents, Lithic Ustorthents, Typic Ustorthents, Typic Udipsamments, Typic Ustipsamments), Mollisols (Typic Hapludolls and Typic Haplustolls), Inceptisols (Fluvaquentic Endoaquepts, Sulfic Endoaquepts Aeric Endoaquepts, Typic Endoaquepts, Typic Epyaquepts, Aquic Eutrudepts, Fluvaquentic Eutrudepts, Lithic Eutrudepts, Typic Eutrudepts, Aquic Haplustepts, Fluventic Haplustepts, Lithic Haplustepts, and Typic Haplustepts), and Alfisols (Typic Hapludalfs and Typic Haplustalfs). Completely of soil types at Buru Island are showing in Table 2.

\section{Land Use of Buru Island}

Landsat image analysis results were equipped with field observational data indicate that the use of land on the island of Buru divided into fields, grass and bushes, shrubs, moor and village, eucalyptus and shrubs, coconut and mixed farms, primary forest, secondary forest, mangrove, sago forest, and open land, such as in Table 3.

Table 2. Soil Types which Found at Buru Island

\begin{tabular}{|c|c|c|c|}
\hline Ordo & Sub Ordo & Group & Subgroup \\
\hline \multirow[t]{2}{*}{ Histosols } & Saprists & Sulfisaprists & Terric Sulfisaprists \\
\hline & Hemists & Sulfihemists & Typic Sulfihemists \\
\hline \multirow[t]{9}{*}{ Entisols } & Aquents & Fluvaquents & Sulfic Fluvaquents \\
\hline & & & Typic Fluvaquents \\
\hline & Fluvents & Udifluvents & Aquic Udifluvents \\
\hline & Orthens & Udorthents & Lithic Udorthents \\
\hline & & & Typic Udorthents \\
\hline & & Ustorthents & Lithic Ustorthents \\
\hline & & & Typic Ustorthents \\
\hline & Psamments & Udipsamments & Typic Udipsamments \\
\hline & & Ustipsamments & Typic Ustipsamments \\
\hline \multirow[t]{2}{*}{ Mollisols } & Udolls & Hapludolls & Typic Hapludolls \\
\hline & Ustolls & Haplustolls & Typic Haplustolls \\
\hline \multirow[t]{9}{*}{ Inceptisols } & Aquepts & Endoaquepts & Fluventic Endoaquepts \\
\hline & & & Sulfic Endoaquepts \\
\hline & & & Aeric Endoaquepts \\
\hline & & & Typic Endoaquepts \\
\hline & & Epiaquepts & Typic Epiaquepts \\
\hline & Udepts & Eutrodepts & Aquic Eutrodepts \\
\hline & & & Fluventic Eutrodepts \\
\hline & & & Lithic Eutrodepts \\
\hline & & & Typic Eutrodepts \\
\hline
\end{tabular}




\begin{tabular}{|c|c|c|c|}
\hline & Ustepts & Haplustepts & $\begin{array}{l}\text { Aquic Haplustepts } \\
\text { Fluventic Haplustepts } \\
\text { Lithic Haplustepts } \\
\text { Typic Haplustepts }\end{array}$ \\
\hline \multirow[t]{2}{*}{ Alfisols } & Udalfs & Hapludalfs & Typic Hapludalfs \\
\hline & Ustalfs & Haplustslfs & Typic Haplustalfs \\
\hline
\end{tabular}

Table 3. Buru Land Use Analysis Based on Landsat Imagery

\begin{tabular}{lrc}
\hline \multicolumn{1}{c}{ Land Use } & Area $(\mathrm{Ha})$ & Percentage $(\%)$ \\
\hline 1. Wetland & 8,900 & 1.03 \\
2. Grass and Shrubs & 2,685 & 0.31 \\
3. Shurblands & 4,014 & 0.47 \\
4. Moor and Kampong & 21,667 & 2.52 \\
5. White Wood and Shrubs & 159,772 & 18.56 \\
6. Coconut and Mixed Garden & 2,212 & 0.26 \\
7. Primary Forest & 422,341 & 49.06 \\
8. Secondary Forest & 193,043 & 22.43 \\
9. Mangrove & 4,554 & 0.53 \\
10. Sago Swamp Forest & 19,785 & 2.30 \\
11. Open Land & 21,814 & 2.53 \\
\hline \multicolumn{1}{c}{ T o t a l } & $\mathbf{8 6 0 , 7 8 7}$ & $\mathbf{1 0 0 . 0 0}$ \\
\hline
\end{tabular}

Sources: Moluccas Provincial Agriculture Office (2008)

\section{Agro-Ecology Zone for Estate Crops}

Buru Island consists of two regency, namely Buru and Southern Buru. Buru regency is administratively divided into 5 districts, namely District Namlea, Air Buaya, Waeapo, Waplau, and Batabual. Similarly, South Buru district consists of 5 districts namely Waisama, Leksula, Kapala Madan, Namrole and Ambalau (In the development of the region, Buru Regency has become 10 districts and Southern Buru Regency to 6 districts). Agro-Ecological Zones of Buru is very diverse. There are five (5) zones are then lowered 15 subzona, that I ax, I bx, I cx, II ax, II ax.i, II ay, II ay.i, IV ax, IV ax.i, IV ay, IV ay.i, IV az, IV az.i, IV bz.i, and VI az (Susanto \& Bustaman 2006). Figures of AEZ map for estate crops in each districts of Buru and Southern Buru Regency shown in Appendix 1 and 2.

In this study, the zoning we boundary only for estate crops including zone II. Zone II having an area of about 34,923.36 ha, which is divided into 4 (four) subzona, namely II axII ax.i, II ay, and II ay.i, while other zones covering an area of 821,134.59 ha, as in Table 4. 
Table 4. Agro-Ecology Zone Extents for Estate Crops at Buru Island (Buru and Southern Buru Regency)

\begin{tabular}{|c|c|c|c|c|c|c|}
\hline \multicolumn{3}{|c|}{ Agroecology } & \multicolumn{2}{|c|}{$\begin{array}{c}\text { Development of Agriculture and } \\
\text { Forestry }\end{array}$} & \multicolumn{2}{|l|}{ Total Area } \\
\hline Sub Zon & Physiographic & $\begin{array}{c}\text { Slope } \\
(\%)\end{array}$ & System & Commodities & Ha & $\%$ \\
\hline I ax & $\begin{array}{l}\text { Mountains, hills, } \\
\text { karst, force, } \\
\text { volcanic, plains }\end{array}$ & $>40$ & Mixed forest & $\begin{array}{l}\text { Natural vegetation, } \\
\text { coconut, cloves, cocoa, } \\
\text { nutmeg. }\end{array}$ & $429,794.24$ & 50.21 \\
\hline I bx & $\begin{array}{l}\text { Mountains, hills } \\
\text { forces, volcanic and } \\
\text { karst }\end{array}$ & $>40$ & Forestry & Natural vegetation & $310,878.50$ & 36.32 \\
\hline I cx & $\begin{array}{l}\text { Mountains, hills } \\
\text { forces, volcanic and } \\
\text { karst }\end{array}$ & $>40$ & Forestry & Natural vegetation & $8,532.81$ & 1.00 \\
\hline II ax & $\begin{array}{l}\text { Terrace, wavy, hilly, } \\
\text { mountains, hills, } \\
\text { plains, force, } \\
\text { vulkan, karst }\end{array}$ & $16-40$ & Agroforestry & $\begin{array}{l}\text { Coconut, oil palm, cocoa, } \\
\text { cloves, nutmeg, walnuts, } \\
\text { durian, banana, duku, } \\
\text { mangostan, jackfruit, } \\
\text { salak, rambutan. }\end{array}$ & $15,952.78$ & 1.86 \\
\hline II ax.i & $\begin{array}{l}\text { Terrace, wavy, hilly, } \\
\text { mountains, hills, } \\
\text { plains, force, } \\
\text { vulkan, karst }\end{array}$ & $16-40$ & Agroforestry & $\begin{array}{l}\text { Coconut, nutmeg, cocoa, } \\
\text { cloves, banana, duku }\end{array}$ & $8,924.26$ & 1.04 \\
\hline II ay & Terrace & $16-40$ & Agroforestry & $\begin{array}{l}\text { Coconut, coffee, cloves, } \\
\text { cashew, mango, } \\
\text { pineapple, watermelon, } \\
\text { bark, banana, eucalyptus, } \\
\text { citrus, cotton }\end{array}$ & $5,887.99$ & 0.69 \\
\hline II ay.i & Terrace & $16-40$ & Agroforestry & $\begin{array}{l}\text { Coconut, coffee, cloves, } \\
\text { cashew, mango, } \\
\text { pineapple, banana, } \\
\text { eucalyptus, citrus }\end{array}$ & $4,158.33$ & 0.53 \\
\hline IV ax & $\begin{array}{l}\text { karst plains, } \\
\text { terraces, fans and } \\
\text { lava, meanders, } \\
\text { alluvial }\end{array}$ & $3-8$ & $\begin{array}{c}\text { Dryland } \\
\text { agricultural }\end{array}$ & $\begin{array}{l}\text { Upland rice, corn, beans, } \\
\text { tubers }\end{array}$ & $4,514.57$ & 0.53 \\
\hline $\begin{array}{l}\text { IV } \\
\text { ax.i }\end{array}$ & $\begin{array}{l}\text { Alluvial, fans and } \\
\text { lava, karst terrain, } \\
\text { terraces, meander }\end{array}$ & $3-8$ & $\begin{array}{c}\text { Dryland } \\
\text { agricultural }\end{array}$ & Corn, beans, tubers & $7,573.51$ & 0.88 \\
\hline IV ay & $\begin{array}{l}\text { Plain, fan and lava, } \\
\text { karst and terraces }\end{array}$ & $3-8$ & $\begin{array}{c}\text { Dryland } \\
\text { agricultural }\end{array}$ & $\begin{array}{l}\text { Upland rice, corn, beans, } \\
\text { tubers }\end{array}$ & $4,070.32$ & 0.48 \\
\hline
\end{tabular}




\begin{tabular}{|c|c|c|c|c|c|c|}
\hline $\begin{array}{l}\text { IV } \\
\text { ay.i }\end{array}$ & $\begin{array}{l}\text { Plain, fan and lava, } \\
\text { karst and terraces }\end{array}$ & $3-8$ & $\begin{array}{c}\text { Dryland } \\
\text { agricultural }\end{array}$ & Corn, beans, tubers & $3,300.58$ & 0.39 \\
\hline IV az & $\begin{array}{l}\text { Alluvial plains, } \\
\text { alluvial valleys and } \\
\text { alluvial river }\end{array}$ & $<3$ & $\begin{array}{c}\text { Wetland } \\
\text { agricultural }\end{array}$ & Rice, horticultura & $27,828.57$ & 3.25 \\
\hline $\begin{array}{l}\text { IV } \\
\text { az.i }\end{array}$ & $\begin{array}{l}\text { Alluvial plains, } \\
\text { alluvial valleys and } \\
\text { alluvial river }\end{array}$ & $<3$ & $\begin{array}{c}\text { Wetland } \\
\text { agricultural }\end{array}$ & Rice, horticultura & $9,685.28$ & 1.13 \\
\hline $\begin{array}{l}\text { IV } \\
\text { bz.i }\end{array}$ & $\begin{array}{l}\text { Alluvial plains, } \\
\text { alluvial valleys and } \\
\text { alluvial river }\end{array}$ & $<3$ & $\begin{array}{c}\text { Wetland } \\
\text { agricultural }\end{array}$ & Rice, horticultura & $2,546.26$ & 0.30 \\
\hline VI az & Tidal swamp & $<2$ & $\begin{array}{l}\text { Shrimp } \\
\text { Fishery }\end{array}$ & coast, crabs, milkfish & $11,385.05$ & 1.33 \\
\hline Lake & & & $\begin{array}{c}\text { Freshwater } \\
\text { carp }\end{array}$ & carp, tilapia, cork, etc & $1,064.80$ & 0.12 \\
\hline & TOTAL & & & & $856,057.95$ & 100.00 \\
\hline
\end{tabular}

\section{Subzona II ax}

Subzona II ax broad is 15,952.78 ha, located in the physiographic porch, wavy, hilly, mountains and hills, plains, force, volcanic, and karst with slopes between $16 \%$ to $40 \%$. This area of the biophysical potential to be developed for the plantation business with yard pattern, monoculture, polyculture and alley cropping. Alternative commodities that can be cultivated are coconut, oil palm, cocoa, clove, nutmeg, walnuts, durian, banana, duku, mangostan, jackfruit, salak and rambutan.

\section{Subzona II ax.i}

This is a broad subzona 8,924.26 ha, located in the same physiographic subzona II ax. Subzona has cultivated plantation society with primary commodities coconut, nutmeg, cocoa, clove, banana and duku. Intensification of plantation needs to be done here to improve farming techniques and increase productivity.

\section{Subzona II ay}

Broad subzona II ay is 5,887.99 ha, located on the terrace physiographic slope between $16 \%$ to $40 \%$. This Subzona for the development of agricultural commodities such as coconut, coffee, cloves, cashew, mango, pineapple, watermelon, bark, banana, eucalyptus, citrus, and cotton.

\section{Subzona II ay.i}

Broad subzona II ay.i is $4,158.33$ ha, located on the terrace physiographic slope between $16 \%$ to $40 \%$. This Subzona for the development of agricultural commodities such as coconut, coffee, cloves, cashew, mango, pineapple, banana, eucalyptus, and citrus. 


\section{Land Potential and Suitability for Development of Estate Crops}

Development of estate crops in Moluccas Province, including on the Buru Island (Buru and Southern Buru Regency) is very fast compared to the potential land available. Based on data AEZ, potential land for estate crops on the Buru Island area of 34,923.36 ha, excluding other uses (forestry, agro-forestry, dry land for food crops, and others) which covers an area of $821,134.59$ ha (Susanto 2013, rationalization of data) (Table 5).

Table 5. Land Potential of Buru Island for Estate Crops Development by AEZ in Zona II

\begin{tabular}{|c|c|c|c|c|c|c|}
\hline \multirow{3}{*}{$\begin{array}{l}\text { Code } \\
\text { AEZ }\end{array}$} & \multirow{3}{*}{ Physiographic } & \multirow{3}{*}{$\begin{array}{r}\text { Slope } \\
(\%)\end{array}$} & \multirow{3}{*}{$\begin{array}{l}\text { Agriculture } \\
\text { System }\end{array}$} & \multirow{3}{*}{$\begin{array}{c}\text { Alternative } \\
\text { Commodities }\end{array}$} & \multicolumn{2}{|c|}{ Land Potential } \\
\hline & & & & & Ha & $\%$ \\
\hline & & & & & & \\
\hline II ax & $\begin{array}{l}\text { Terrace, wavy, } \\
\text { hilly }\end{array}$ & $16-40$ & Agro-forestry & $\begin{array}{l}\text { Coconut, palm oil, } \\
\text { nutmeg, cocoa, } \\
\text { clove, rambutan, } \\
\text { durian, banana, } \\
\text { duku, mangostan, } \\
\text { salak }\end{array}$ & $15,952.78$ & 1.86 \\
\hline $\begin{array}{l}\text { II } \\
\text { ax.i }\end{array}$ & $\begin{array}{l}\text { Terrace, wavy, } \\
\text { hilly }\end{array}$ & $16-40$ & $\begin{array}{l}\text { Intensification } \\
\text { of } \\
\text { agro-forestry }\end{array}$ & $\begin{array}{l}\text { Coconut, nutmeg, } \\
\text { cocoa, clove, durian }\end{array}$ & $8,924.26$ & 1.04 \\
\hline II ay & $\begin{array}{l}\text { Terrace, wavy, } \\
\text { hilly }\end{array}$ & $16-40$ & Agro-forestry & $\begin{array}{l}\text { Coconut, coffee, } \\
\text { clove, mango, } \\
\text { cashew, nanas, } \\
\text { watermelon, salak, } \\
\text { banana }\end{array}$ & $5,887.99$ & 0.69 \\
\hline $\begin{array}{l}\text { II } \\
\text { ay.i }\end{array}$ & $\begin{array}{l}\text { Terrace, wavy, } \\
\text { hilly }\end{array}$ & $16-40$ & $\begin{array}{l}\text { Intensification } \\
\text { of } \\
\text { agro-forestry }\end{array}$ & $\begin{array}{l}\text { Coconut, coffee, } \\
\text { clove, cashew } \\
\text { banana. }\end{array}$ & $4,158.33$ & 0.49 \\
\hline \multicolumn{5}{|c|}{ Total II (ax, ax.i, ay, ay.i) } & $34,923.36$ & 4.08 \\
\hline \multicolumn{5}{|c|}{$\begin{array}{l}\text { Other uses (forestry, agroforestry, drylands, wetlands, ponds, coastal forests, and } \\
\text { lakes) }\end{array}$} & $821,134.59$ & 95.92 \\
\hline Total & & & & & $856,057.95$ & 100.00 \\
\hline
\end{tabular}

Existing plantation area in Buru Island (Buru and Southtern Buru Regency) in 2016 of 40,734 ha, far in excess of the total potential of the land based on the data AEZ, consists of 15,686 ha of coconut, 10,897 ha of cocoa, clove 8,740 ha, 252 ha of coffee, nutmeg 3,985 ha, and 1,174 ha of cashew (CBS of Buru Regency 2017; CBS of Southern Buru Regency 2017).

This is presumably because some things, namely (1) the data of land use for agricultural commodities overlap because each commodity is calculated based on the plantation, the thing on the ground is mixed farms, and (2) the use of land for plantations have exceeded their addresses which may have been using the agricultural zone dry land (zone IV), agro-forestry zone (III) or forest zone (zone I).

Based on data from Institution of Agriculture Moluccas Province in 2008, the potential of land for plantation crops in Buru area of 169,979 ha, consisting of suitable class (S1) covering an area of 51,597 ha, is enough suitable class (S2) covering an area of 54,235 ha, 
and the marginally suitable (S3) covering an area of 64,147 ha, while the class is not in accordance measuring 690,809 ha (Moluccas Provincial Agriculture Office 2008), as shown in Table 6.

Table 6. Land Suitability for Development of Estate Crops on Buru Island (Buru and Southern Buru Regency)

\begin{tabular}{|c|c|c|c|c|c|}
\hline \multirow{2}{*}{$\begin{array}{c}\text { Land } \\
\text { Suitability }\end{array}$} & \multirow{2}{*}{ Limiting Factor } & \multicolumn{2}{|c|}{ Area (Ha) } & \multicolumn{2}{|c|}{ Total Area Potential } \\
\hline & & Buru & Southern Buru & $\mathrm{Ha}$ & $\%$ \\
\hline $\begin{array}{l}\text { Suitable } \\
\text { (S1) }\end{array}$ & Drainage, rooting conditions & 33,260 & 18,337 & 51,597 & 6.00 \\
\hline $\begin{array}{l}\text { Enough } \\
\text { Suitable } \\
\text { (S2) }\end{array}$ & $\begin{array}{l}\text { Nutrient retention, slope, rooting } \\
\text { conditions, flood hazards, water supply }\end{array}$ & 28,629 & 25,606 & 54,235 & 6.30 \\
\hline $\begin{array}{l}\text { Marginally } \\
\text { Suitable (S3) }\end{array}$ & $\begin{array}{l}\text { Rather steep slope, rooting conditions, the } \\
\text { availability of water }\end{array}$ & 35,843 & 28,304 & 64,147 & 7.45 \\
\hline $\begin{array}{l}\text { Not Suitable } \\
\text { (N) }\end{array}$ & $\begin{array}{l}\text { A steep slope, rooting conditions, floods, } \\
\text { temperature, nutrient retention, water } \\
\text { supply, drainage, sulfidic danger. }\end{array}$ & 362,877 & 327,932 & 690,809 & 80.25 \\
\hline & TOTAL & 460,609 & 400,179 & 860,788 & 100.00 \\
\hline
\end{tabular}

\section{Condition of Estate Crops at Buru Island}

Estate crops that occupy the largest planting area on Buru Island is coconut. Area of coconut cultivation on Buru Island in year 2016 amounted to 15,684 ha, much higher compared to other commodities (Table 7). The second and third larged planting area is cacao and cloves, each 10,897 and 8,740 ha, respectively.

Table 7. Average Acreage and Production of Estate Crops in Buru and Southern Buru Regency (Buru Island) in 2016

\begin{tabular}{lrrrrrr}
\hline \multirow{2}{*}{ Commodities } & \multicolumn{2}{c}{ Buru Regency } & \multicolumn{2}{c}{ Southern Buru Regency } & \multicolumn{2}{c}{ Total (Buru Island) } \\
\cline { 2 - 7 } & $\begin{array}{r}\text { Area planted } \\
\text { (Ha) }\end{array}$ & $\begin{array}{c}\text { Production } \\
\text { (Ton) }\end{array}$ & $\begin{array}{c}\text { Area planted } \\
\text { (Ha) }\end{array}$ & $\begin{array}{c}\text { Production } \\
\text { (Ton) }\end{array}$ & $\begin{array}{c}\text { Area planted } \\
\text { (Ha) }\end{array}$ & $\begin{array}{c}\text { Production } \\
\text { (Ton) }\end{array}$ \\
\hline Clove & 1,252 & 448 & 7,488 & 2,197 & 8,740 & 2,645 \\
Nutmeg & 1,242 & 29 & 2,743 & 4,625 & 3,985 & 4,654 \\
Coconut & 4,996 & 3,091 & 10,690 & 9,496 & 15,686 & 12,587 \\
Cocoa & 4,687 & 4,050 & 6,210 & 4,098 & 10,897 & 8,148 \\
Coffee & 130 & 62 & 122 & 40 & 252 & 102 \\
Cashew & 1,174 & 625 & - & - & 1,174 & 625 \\
\hline
\end{tabular}

Sources : CBS of Buru and Southern Buru Regency (2017) (data reprocessed) 


\section{Conclusions}

Based on the analysis of Agro-Ecology Zone map, land potential of Buru Island for development of estate crops was area of 34,923.36 ha (4.08\%) of the total area of Buru Island, spread on subzona IIax, IIax.i, Ilay and IIay.i. The area does not include dryland for food and agroforestry.

Based on data from Institute of Agriculture Moluccas Province, land suitablity for estate crops of Buru Island area of 169,979 ha, consisting of suitable class (S1) covering an area of 51,597 ha, is enough suitable class (S2) covering an area of 54,235 ha, and the marginally suitable (S3) covering an area of 64,147 ha.

Coconut, cocoa and cloves are the three estate crops that occupy the widest area on Buru Island, but nutmeg plant is one of the potential estate crops to be developed.

\section{References}

CBS [Central Bureau of Statistics] of Buru Regency. 2017. Buru In Figures 2016. Central Bureau of Statistics Buru Regency.

CBS [Central Bureau of Statistics] of Southtern Buru Regency. 2017. Southtern Buru In Figures 2016. Central Bureau of Statistics Southtern Buru Regency.

Dent D and A Young. 1981. Soil Survey and Land Evaluation. George Allen and Unwin London.

Department of Agriculture. 1997. Suitability Criteria for Soil and Climate Crop. Planning Bureau, Jakarta.

Djaenudin D, Basuni Hw, K Nugroho, M You and U Sutrisno. 1993. Technical Guidelines for Land Evaluation. Research Center for Soil and Agro-climate cooperation with the National Agricultural Research Development Project, Agency for Agricultural Research and Development, the Department of Agriculture.

Djaenudin D, Marwan H, H Subagyo, A Mulyani and Nata Suharta. 2003. Land suitability criteria for agricultural commodities. Version 3 in 2000. Centre for Research and Development of Soil and Agro-Climate, Bogor.

FAO. 1976. A Framework for Land Evaluation. Soil Resources Management and Conservation Service Land and Water Development Division. FAO Soil Bulletin No. 32. FAO-UNO, Rome.

Hakim N, MY Nyakpa, AM Lubis, SG Nugroho, MR Saul, MA Su, Go Ban Hong and H Bailey. 1986. Fundamentals of Soil Science. University of Lampung.

Kasryno F, Erwidodo, E Fasandaran, I W Rusastra, AM Fagi and T Panji. 2002. Thinking About Vision Indonesian Agricultural Development in 2002 and Implications for Agricultural Research. Pros. Policy Direction and Styrategi Operational Programme for Agricultural Research 2003. pp. 22-57. AARD, Jakarta. 


\section{Macrothink}

Journal of Agricultural Studies

ISSN 2166-0379

2018, Vol. 6, No. 3

Moluccas Provincial Agriculture Office 2008. Annual Report of Moluccas Provincial Agriculture Office.

Soil Survey Staff. 1998. Soil Survey Manual. USDA Handbook No. 18. United States Departement of Agriculture Washington DC.

Susanto AN. 2013. The Rationalization of Data from ZAE, Land Suitability Evaluation and Present Landuse Satelite Imagery Evaluation and Statistics 4 Last Year (2009-2012).

Susanto AN and S Bustaman. 2006. Data and Information Land Resources to Support Agricultural Development in Maluku Islands Region. AIAT Maluku, AARD. 73 p.

Ritung S, K Nugroho, A Mulyani and E Suryani. 2011. Technical Guidelines for Land Evaluation of Agricultural Commodity (Revised Edition). Research and Development Center for Agricultural Land Resources, Agency for Agricultural Research and Development, Ministry of Agriculture.

Rossiter DG.1994. Basic Concepts and Procedures of Land Evaluation. In Lecture Notes: Land Evaluation. College of Agriculture and Life Sciences, Depart. of Soil, Crop \& Atmospheric Sciences. SCAS Teaching Series T94-1. Cornell University.

Rossiter DG and AR van Wambeke. 1997. Automated Land Evaluation Syatem ALES Version 4.65d User's Manual. Cornell Univ. Dept. of Soil Crop \& Atmospheric Sci. SCAS. Ithaca, NY, USA.

Wiradisastra US. 1996. Delineation of Agro-Ecological Zones. Papers on Training Methodology Appreciation Delineation Agro-Ecological Zones. Institutional Development Project Agricultural Research and Development in collaboration with the Faculty of Agriculture IPB, Bogor, 8-17 January 1996.

\section{Appendix}

Appendix 1. Figures of AEZ Map for Development of Estate Crops in Each District of Buru Regency
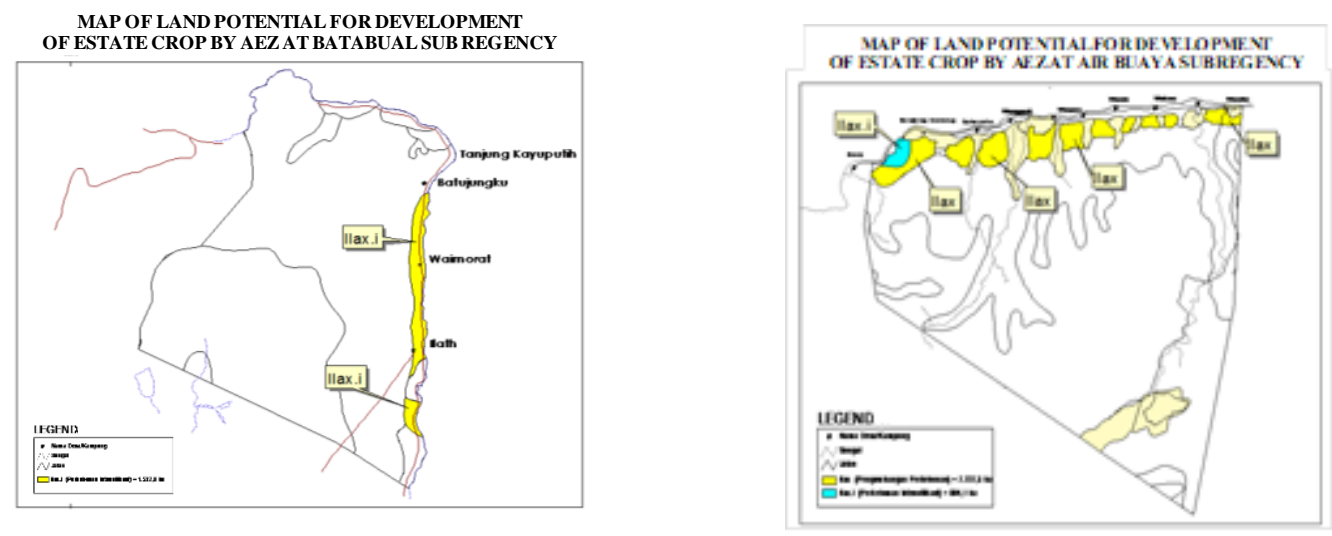

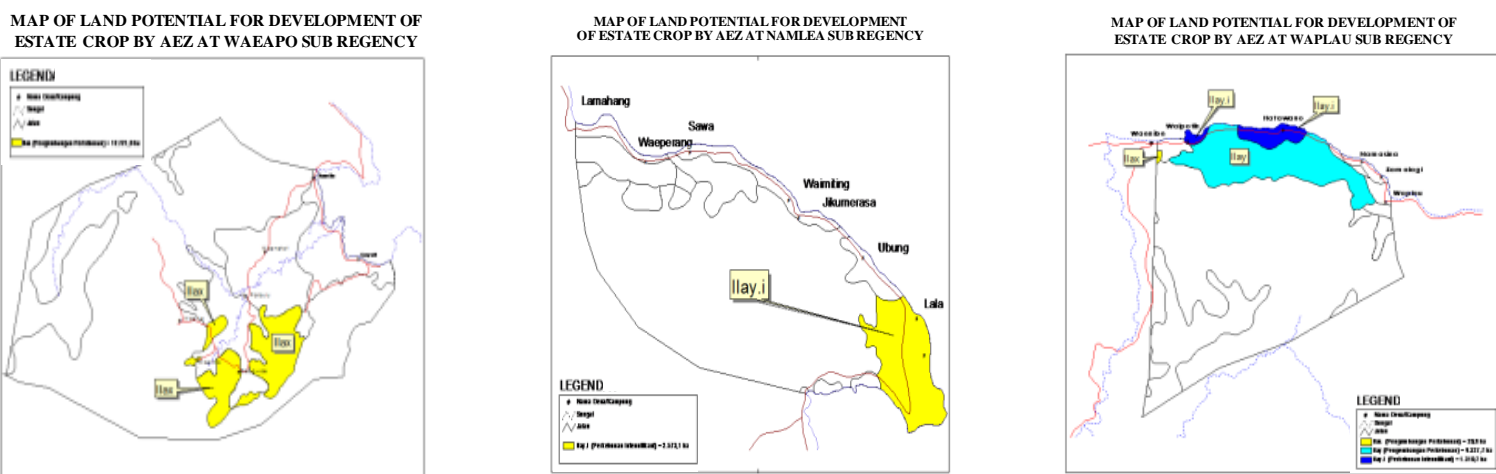

Appendix 2. Figures of AEZ Map for Development of Estate Crops in Each District of Southern Buru Regency
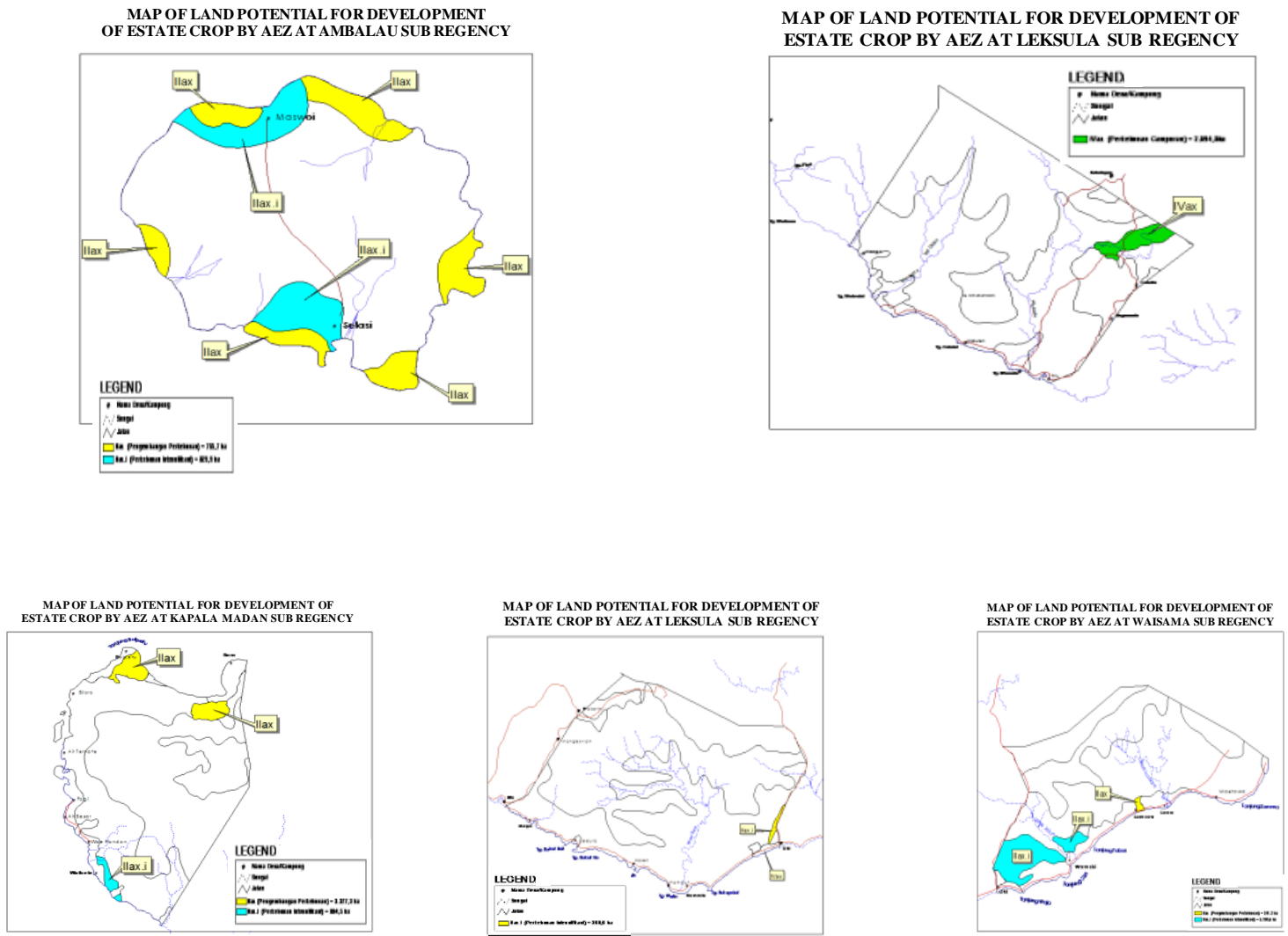

\section{Copyright Disclaimer}

Copyright for this article is retained by the author(s), with first publication rights granted to the journal.

This is an open-access article distributed under the terms and conditions of the Creative Commons Attribution license (http://creativecommons.org/licenses/by/4.0/). 